\title{
Liposomal Amphotericin B Usefulness in Critical Care Unit: A Review Study
}

\author{
Elham Nikzad, ${ }^{1}$ Fatemeh Abdollahi, ${ }^{1}$ and Seyed Mohammadreza Hashemian ${ }^{1,{ }^{*}}$ \\ ${ }^{1}$ Chronic Respiratory Disease Research Center, National Research Institute of Tuberculosis and Lung Disease, Shahid Beheshti University of Medical Sciences, Tehran, IR Iran \\ "Corresponding author: Professor Seyed Mohammadreza Hashemian, MD.FCCM, Education Manager of SBMU Critical Care Fellowship Program, Tehran, IR Iran. Tel: \\ +98-9121119279, E-mail: smrhashemian@sbmu.ac.ir
}

Received 2015 November 30; Accepted 2016 January 12.

\begin{abstract}
During the last 3 decades, the prevalence and variety of invasive fungal infections increased, especially in the critically ill patients thanks to advances in medical sciences, modification of the instruments, drugs, and protective-therapeutic methods. Such infections are administered by 4 pharmaceutical classes as follows: 1. Polyenes; 2 . Azoles; 3 . Echinocandins; 4 . Pyrimidine analogues. One of these drugs is polyenes consisting of amphotericin and its lipid-based formulation. The lipid formulation of this drug is used due to its fewer side effects compared with the conventional type of the drug that makes it possible to enhance the drug efficacy by increasing the administered dosage. This pharmaceutical class is used to treat the following diseases in the critically ill patients: candidiasis, invasive aspergillosis, mucorales infection, cryptococcal meningoencephalitis, visceral leishmaniosis, persistent fever and neutropenia, renal replacement therapy (RRT) in intensive care unit (ICU), kidney transplantation, and liver problems. Now, the word health organization (WHO) approved liposomal amphotericin B (AmB) as the first-line treatment of visceral leishmaniosis in the Eastern Africa. It was even used with a single dose of $10 \mathrm{mg} / \mathrm{kg}$ with $95 \%$ efficacy. The current study aimed at investigating the effect of amphotericin and its lipid formulation to treat the aforementioned diseases.
\end{abstract}

\section{Introduction}

The prevalence and variety of invasive fungal infections increased over the last 3 decades due to the following reasons:

Changes occurred in the medical care and surgery, especially in the ICU, including the use of invasive catheters to monitor the patients, the use of agents and drugs that weaken the immune system, long-term treatment with wide-range ABs (1), the use of protective methods such as ventilator, hemodialysis, venous hemofiltration, hyperalimentation, and the use of antineoplastic and transplantation (of organs and bone marrow) therapeutic methods in patients with liver, kidney, and cardiopulmonary diseases in their background. Due to these medical advances and therapeutic achievements, the population at risk for fungal infections considerably increased and resulted in a change in the approaches adopted toward fungal infections (2,3).

Today, systemic fungal infections are among the serious problems, especially in the intensive care units (ICUs) because many of the critically ill patients have a weak immune system due to the reasons mentioned above $(4,5)$. Invasive fungal diseases are the important reasons in the mortality and morbidity of the patients with immune deficiency and are also related to the increased health care costs (6). Now, fungal infections, especially candidiasis and aspergillosis, are considered as new health problems in the critically ill patients including those receiving transplants (7).

There were many advances in the antifungal treatments over the last decades. The 4 categories of antifungal drugs used to treat the critically ill patients with invasive fungal infections include polyenes, azoles, echinocandins, and pyrimidine analogues.

The functioning of the polyenes category is investigated here:

\subsection{Polyenes (amphotericin B)}

The deoxycholate AmB is used as the main medicine to treat the invasive fungal infections for a number of decades. This drug covers a wide spectrum of fungal infections. Table 1 presents the efficacy of this pharmaceutical class in different fungal species.

The AmB has fungicidal effects and its efficacy is based on the drug capacity to link with ergosterol, and the main sterol constituting the cell membrane. It disturbs osmotic 


\begin{tabular}{|c|c|c|c|}
\hline Microorganism & Polyenes Activity & Microorganism & Polyenes Activity \\
\hline Candida albicans & 1st-line & Aspergillus fumigates & 2nd-line \\
\hline Candida glabrata & 2nd-line & Aspergillus terreus & No activity \\
\hline Candida tropicalis & 1st-line & Fusarium sp. & 2nd-line \\
\hline Candida parapsilosis & 1st-line & Scedosporium apiospermum & Unknown \\
\hline Candida krusei & 2nd-line & Scedosporium prolificans & Unknown \\
\hline Candida guilliermondii & 2nd-line & Trichosporon spp. & 3rd-line \\
\hline Candida Lusitaniae & 2nd-line & Zygomycetes (e g, Lichtheimia., Macor., and Rhizopus spp.) & 1st-line \\
\hline Cryptococcus neoformans & 1st-line & $\begin{array}{l}\text { Dematiaceous molds (e g, Alternaria, Bipolaris, Curvularia, and Exophiala } \\
\text { spp.) }\end{array}$ & 3rd-line \\
\hline \multirow[t]{5}{*}{ Aspergillus flavus } & 2nd-line & Dimorphic fungi: & \\
\hline & & Blastomyces dermatitidis & 1st-line \\
\hline & & Coccidioides immitis & 1st-line \\
\hline & & Histoplasma capsulatum & 1st-line \\
\hline & & Sporothrix schenckii & 1st-line \\
\hline
\end{tabular}

equilibrium in the cell membrane, increases the permeability of the cell membrane and consequently results in the subsidence of the cell ingredients and the death of fungal cells (7-9).

In spite of the long usage of this drug, no considerable resistance to this pharmaceutical class is observed, except in the following cases:

C. glabrata and C. krusei need higher degrees of MICs (minimum inhibitory concentrations) (10) and filamentous fungi (Aspergillus species) have higher resistance compared with polyenes (11). The use of conventional AmB is restricted due to the narrow therapeutic window and its side effects, specifically the nephrotoxicity (12). The danger of nephrotoxicity increases when it coincides with other nephrotoxic drugs such as aminoglycosides, antineoplastic drugs, cidofovir, cyclosporine, Foscarnet and pentamidine (13). The nephrotoxicity is a progressive disorder in kidney functions related to hypokalemia, tubular acidosis, and hypocalcemia (7). Another major problem of injecting AmB is its side effects including fever and chills, headache, myalgia and rigors. To decrease these side effects, slow infusion and infusion with acetaminophen and hydrocortisone are recommended (14).

Some lipid forms of the drug AmBs decrease the problems caused by conventional type of the drug. These formulations include (14-16)

- Liposomal amphotericin B (Lip AmB)

- Amphotericin B lipid complex (ABLC)

- Amphotericin B colloidal dispersion(ABCD)

The lipid-based formulations of the amphotericin have fewer nephrotoxic effects than the conventional type (7). Their effect is same as that of the conventional type $(14,15)$. However, they have a better safety profile (17) and the reac- tions/side effects of AmB infusion are less severe and less frequent in the lipid formulations of this drug (14). Nevertheless, the lipid formulations are more expensive than the conventional type $(7,13)$. The combination of AmpB with liposomes results in a decreased interaction of $A m p B$ with the mammals' cells while maintaining the multifungal property of the drug (18). Various studies showed a good clinical tolerance of Lip AmB (19-22). The liposomal type decreases the side effects such as fever and chills and protects against nephrotoxicity (23). Due to the low degree of Lip AmB toxicity, the drug dose can be considerably increased, which result in the increased efficacy of the drug $(24,25)$. However, side effects such as anemia, thrombocytopenia, nephrotoxicity, and hepatotoxicity are reported for Lip AmB and the first 2 side effects are dose-limited (26). Nevertheless, it seems that Lip AmB has less degrees of toxicity compared with the other 2 lipid formulations (13). The contraindication to this pharmaceutical class is hypersensitivity to AmpB and there is a possibility of anaphylaxis (7). The major side effects and the interactions of this pharmaceutical class can be observed in Table 2 . Notice that this pharmaceutical class does not intervene in a cytochrome P450-dependent pathway (7).

The type and dose of polyene pharmaceutical class are shown in brief in Table 3 (7).

The role of polyenes (amphotericin and its lipid formulations) in the control of fungal infections:

1. Candida spp.

In contrast to the 2004 guideline, the 2009 IDSA guideline (infectious disease society of America) introduces the AmB and its lipid formulations as alternative therapy for candidemia (28). Such a change is due to the fact that this pharmaceutical class is nephrotoxic (29). However, in a 


\begin{tabular}{|c|c|c|}
\hline Polyenes & Major Side Effects & Drug Interactions \\
\hline 1) Amphotericin B & $\begin{array}{l}\text { Nephrotoxicity, infusion-related reaction, pain at } \\
\text { the site of injection, phlebitis, thrombophlebitis, } \\
\text { cardiopulmonary (cardiac arrest, hypotension, } \\
\text { tachypnea, and arrhythmia) anemia, } \\
\text { thrombocytopenia, leukopenia, coagulation } \\
\text { defect, anorexia, nausea, diarrhea, generalized } \\
\text { pain, muscle, joint pain, headache, anaphylactic } \\
\text { reaction, bronchospasm, wheezing, rash, acute } \\
\text { liver failure, hepatitis, jaundice, convulsion, and } \\
\text { hearing loss }\end{array}$ & $\begin{array}{l}\text { Antineoplastic agents, corticosteroids and } \\
\text { corticotrophin, digitalis glycosides, flucytosine, } \\
\text { azoles, other nephrotoxic medications, skeletal } \\
\text { muscle relaxants, and leucocyte transfusion }\end{array}$ \\
\hline 2) Liposomal amphotericin B & $\begin{array}{l}\text { Infusion related reaction, renal toxicity, chest } \\
\text { pain, hypotension, tachycardia, diarrhea, nausea, } \\
\text { vomiting, abdominal pain, bilirubinemia, liver } \\
\text { enzymes elevation, hypokalemia, } \\
\text { hypomagnesemia, anxiety, headache, lung } \\
\text { disorder, pleural effusion, and rash }\end{array}$ & Same as above \\
\hline Amphotericin Bcolloidal dispersion & $\begin{array}{l}\text { Infusion-related reaction, renal toxicity, } \\
\text { hypotension, tachycardia, abdominal pain, } \\
\text { hypokalemia, diarrhea, nausea vomiting, rash, } \\
\text { dyspnea, asthma, confusion, and dizziness, } \\
\text { cardiac toxicity }\end{array}$ & $\begin{array}{l}\text { Antineoplastic agents, corticosteroids and } \\
\text { corticotrophin, digitalis glycosides, and azoles }\end{array}$ \\
\hline Amphotericin B lipid complex & $\begin{array}{l}\text { Infusion-related reactions, increased serum } \\
\text { creatinine, cardiopulmonary (hypotension, } \\
\text { tachypnea, arrhythmia, pleural effusion, } \\
\text { anaphylactic reaction (bronchospasm, wheezing, } \\
\text { and asthma), rash, acute liver failure, hepatitis, } \\
\text { jaundice, nausea vomiting, abdominal pain, } \\
\text { headache, renal toxicity dosedependent, muscle, } \\
\text { joint pain, convulsion, and tinnitus }\end{array}$ & Same as above \\
\hline
\end{tabular}

${ }^{\mathrm{a}}$ Cardiac toxicity is a rare phenomenon that results in AV block through an unknown mechanism that can be attributed to the change by the drug in the depolarization of the myocardial membrane (27).

\begin{tabular}{llc}
\hline Table 3. Principle Indications of Polyenes and dosing Schedule & Dosing Schedule \\
\hline Agent & Indications & $0.3-1.5 \mathrm{mg} / \mathrm{kg}$ \\
\hline Amphotericin B & $\begin{array}{l}\text { Invasive fungal infections include aspergillosis, cryptococcosis, } \\
\text { North American blastomycosis, systemic candidiasis, } \\
\text { coccidioidomycosis, histoplasmosis, and zygomycosis, as well as } \\
\text { Conidiobolus Basidiobolus species, and Sporotrichosis. }\end{array}$ & \\
\hline Liposomal amphotericin B & $\begin{array}{l}\text { Empirical therapy in patients with febrile neutropenic } 3 \mathrm{mg} / \mathrm{kg} / \mathrm{day} \\
\text { Cryptococcal meningitis in patients with HIV } 6 \mathrm{mg} / \mathrm{kg} / \mathrm{day} \text { Visceral } \\
\text { leishmaniosis }\end{array}$ & $3 \mathrm{mg} / \mathrm{kg} / \mathrm{day} ; 6 \mathrm{mg} / \mathrm{kg} / \mathrm{day} ; 3-4 \mathrm{mg} / \mathrm{kg} / \mathrm{day}$ \\
\hline ABCD & No primary indication; only salvage therapy & $3-6 \mathrm{mg} / \mathrm{kg}$ \\
\hline ABLC & No primary indication; only salvage therapy & $5 \mathrm{mg} / \mathrm{kg}$ \\
\hline
\end{tabular}

number of studies it is stated that in case preventive factors such as enough hydration by means of normal saline, electrolytes replacement and continuous drug infusion occur, the nephrotoxicity is not considered an issue and the efficacy of this drug remains the same as that of the new generation of drugs $(7,30)$. Yet, it should be noted that prehydration can be problematic in the patients receiving transplants because people with nephron and liver problems usually have volume overload and a low level of serum albumin that can result in patients' experiencing a pulmonary reaction similar to pulmonary edema while receiving AmpB and its lipid formulations (31).

To treat candidemia and the documented invasive candidiasis in non-neutropenic patients, based on the following guidelines, the $\mathrm{AmpB}$ and its lipid formulations were selected as alternative therapy (13):

1. IDSA (28)

2. European society of clinical microbiology and infec- 
tious disease (ESCMID) (32)

3. European expert opinion (33)

4. Canadian clinical practice guidelines for invasive candidiasis in adults (34)

5. Joint recommendation of german speaking mycological society (35)

Based on the IDSA guideline, AmpB and its lipid formulations along with fluconazole, echinocandins, and voriconazole are among the therapeutic choices for candidiasis in the ICU (28) and they are selected as an alternative therapy under the following conditions: resistance to fluconazole and echinocardin, resistant infections or infections suspicious of having other pathogens (except for Candida spp.) such as Cryptococcus spp. (29).

According to ESCMID 2011 guideline, it is advised to use echinocardins in invasive Candida infections, as the first choice before Lip AmB (the second selection) and fluconazole (the third selection) (29). However, in the official statement of the American society, it is stated that in invasive Candida infections, in the case of hemodynamic instability, the AmB, Lip AmB, echinocandins, voriconazole, or a high-dose fluconazole should be administered (36).

The German speaking mycological society and the Paul-Elrich society advise the administration of echinocandins and Lip AmB for critically ill and septic patients with invasive Candida infections (35).

With regard to the mentioned guidelines, the algorithm 1 (Figure 1) is suggested to treat patients with invasive Candida infections in ICU (13).

A combination of $A m B$ and flucytosine is suggested to treat localized candidiasis infections such as meningitis, osteomyelitis, and intra-abdominal Candida infections (35). Table 4 presents the therapeutic dose and the therapy duration for the localized invasive candida infections.

\section{Invasive Aspergillosis}

Invasive aspergillosis is the most important invasive fungal disease in patients with weakened immune systems. There is a $10 \%$ probability of its occurrence in allogeneic bone marrow transplant receivers (37) and a 58\% mortality probability $(43.87 \%$ dependent on the underlying disease) (38). Therefore, compared with patients without aspergillosis, patients with aspergillosis need longer hospitalization and higher therapeutic costs $(39,40)$. Due to its great importance, even in the case of clinical suspicion to invasive pulmonary aspergillosis, the antifungal therapy should begin. In the past, AmB was used to treat invasive fungal infections. However, reports of aspergillosis' resistance to this drug and its side effects restricted the application of this drug (41) and today, voriconazole and lipAmB are used to treat invasive fungal diseases such as invasive aspergillosis (39). A combination of these 2 drugs cannot be used because it causes antagonistic effects (42). It is approved that the lipid formulations of $A m B$ can be used as a salvage therapy in the invasive pulmonary aspergillosis with a dose of $3-5 \mathrm{mg} / \mathrm{kg} / \mathrm{day}$, and although the high dose of these formulations $(10 \mathrm{mg} / \mathrm{kg} /$ day $)$ is as effective as the low dose, there is a higher probability of poisoning (43). It is observed that in the critically ill patients, a combination of AmB lipid formulations with echinocandins can be effective to treat the invasive aspergillosis (44).

3. Mucorales Infection

Upon the diagnosis of the mucorales infection, the Lip AmB usage should begin with $5-10 \mathrm{mg} / \mathrm{kg} /$ day. If the intracerebral is infected too, the maximum dose should be used. As the second line of treatment, posaconazole can be used twice a day, with a dose of $400 \mathrm{mg}$. This drug can be used in combination with Lip AmB. It should be noted that besides the mentioned drug therapy, the treatment of mucor needs surgery interventions and the treatment of underlying medical problems.

\section{Cryptococcal meningoencephalitis}

Cryptococcal meningoencephalitis is a fatal opportunistic infection. The global burden of this disease is related to the epidemics of HIV/AIDS especially in the subSahara in Africa (45). It also occurs in other patients with immune deficiency including the solid organ transplant receivers and the therapy consists of an intense period of treatment including AmpB formulations (46). The lipid formulations of amphotericin are known as the first line of the treatment of cryptococcal meningoencephalitis (47).

According to IDSA, it is suggested that Lip AmB with or without flucytosine be used to treat cryptococcal meningitis resulted from HIV/AIDS. In addition, a combined therapy is recommended for the patients undergoing transplantation. So far, different therapeutic regimes are defined to treat this infection including (46).

\section{Lip AmB $6 \mathrm{mg} / \mathrm{kg} / \mathrm{day}$}

2. Lip AmB $3 \mathrm{mg} / \mathrm{kg} /$ day + flucytosine $50 \mathrm{mg} / \mathrm{kg} /$ day

3. Lip AmB $3 \mathrm{mg} / \mathrm{kg} /$ day + flucytosine $100 \mathrm{mg} / \mathrm{kg} /$ day

Among the mentioned regimens, the regimen number 2 had the highest antifungal effects and the least toxicity compared to the other doses (47).

5. Visceral leishmaniosis

Visceral leishmaniosis, also known as Kala-Azar, is a parasitic life- threatening disease (protozoan parasite). The agent creating it is Leishmania donovani that is transferred by the phlebotomus, usually observed in the tropical regions (48). Visceral leishmaniosis is the second fatal parasitic disease after malaria and it afflicts 200,000 to 400,000 people annually (49). Over $90 \%$ of visceral leishmaniosis cases are observed in India, Bangladesh, Nepal, Brazil, South Sudan, and Ethiopia (49), half of which live 


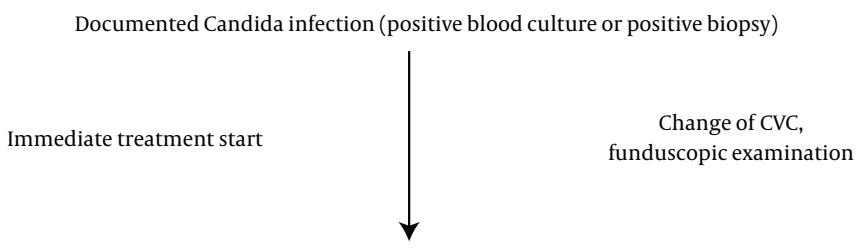

Is the patient haemodynamically stable?
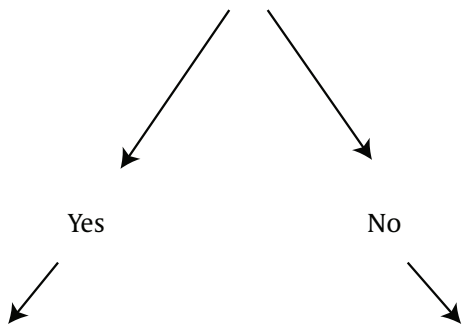

Fluconazole if:

- No recent fluconazole use

- No NAS suspected

- No Intolerance to azoles

- Known local epidemiology
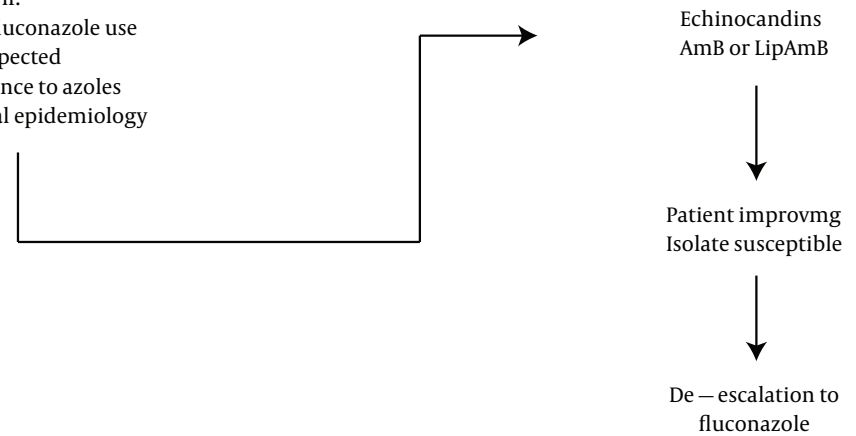

(NAS: non- albicans species, CVC: central venous catheter, AmB: amphotericin B, LipAmB: liposomal amphotericin B).

\begin{tabular}{|c|c|c|c|}
\hline Infection Type & Suggested Treatment & Infection Type & Suggested Treatment \\
\hline Pyelonephritis & AmB $0.3-0.6 \mathrm{mg} / \mathrm{kg} / \mathrm{d}$ for $1-7$ days & CNS infection & $\begin{array}{l}\text { Lip AmB } 3 \text { - } 5 \mathrm{mg} / \mathrm{kg}( \pm 5 \text { FTC } 25 \\
\mathrm{mg} / \mathrm{kg} / \text { qid }) \text { several weeks, then } \\
\text { fluconazole }(6-12 \mathrm{mg} / \mathrm{kg} / \mathrm{d})\end{array}$ \\
\hline Urinary fungus ball & $\begin{array}{l}\text { Surgical removal recommended } \mathrm{AmB} \\
0.5-0.7 \mathrm{mg} / \mathrm{kg} / \mathrm{d}\end{array}$ & Endocarditis & $\begin{array}{l}\text { Lip AmB } 3-5 \mathrm{mg} / \mathrm{kg}( \pm 5 \text { FTC } 25 \mathrm{mg} / \mathrm{kg} \\
\text { qid) or AmB } 0.6-1 \mathrm{mg} / \mathrm{kg} / \mathrm{d}( \pm 5 \text { FTC } 25 \\
\mathrm{mg} / \mathrm{kg} \text { ) or echinocandin }\end{array}$ \\
\hline Candida osteomyelitis & $\begin{array}{l}\text { Lip AmB } 3 \text { - } 5 \mathrm{mg} / \mathrm{kg} / \mathrm{d} \text { (weeks), then } \\
\text { fluconazole for } 6 \text { - } 12 \text { months }\end{array}$ & Supportive thrombophlebitis & Lip AmB 3 - 5 mg/kg/d or echinocandins \\
\hline Septic arthritis & $\begin{array}{l}\text { LipAmB } 3 \text { - } 5 \mathrm{mg} / \mathrm{kg} / \mathrm{d} \text { (weeks), then } \\
\text { fluconazole }\end{array}$ & Endophthalmitis & $\begin{array}{l}\text { AmB } 0.7-1 \mathrm{mg} / \mathrm{kg} \text { plus } 5 \text { FTC or Lip AmB } 3 \\
\text { - } 5 \mathrm{mg} / \mathrm{kg} / \mathrm{d} \text { (or voriconazole or } \\
\text { echinocandins) }\end{array}$ \\
\hline
\end{tabular}

${ }^{\mathrm{a}}$ It should be noted that in all of the above cases, except for the endocarditis, fluconazole can also be used singly as a therapeutic selection.

in India (50).

The parasite migrates to internal organs such as liver, spleen, and bone marrow and leads to persistent fever, hepatosplenomegaly, severe anemia, and a severe damage to the host's immune system (48). In case it is not cured, almost always it leads to death, most often after a secondary opportunistic infection such as pneumonia, tuberculosis and dysentery (51). Since no effective method is known to 
control the carrier phlebotomus, the point to count on in the disease control is to find patients and treat them (52). During the recent decades, the treatment of this disease is based on the intramuscular (IM) injection of antimonial (48). Although these drugs are effective, they have a high degree of toxicity and in complicated cases, and result in mortality (53). Treatment with these drugs needs long hospitalization and in some regions such as India, the disease is resistant to them (48).

Lip AmB is a drug with high application and low toxicity and at present, it is considered as the preferred therapy to treat visceral leishmaniosis in high-income countries (54). Moreover, it was recommended and approved by the world health organization (WHO) as the first-line drug for visceral leishmaniosis in the East Africa since 2010 (51). Lip AmB is also used in cases of complicated initial visceral leishmaniosis and in the relapse of visceral leishmaniosis and in patients with the contraindication of paromomycin and antimonial agents (51). It seems that despite being expensive, Lip AmB is safe to treat visceral leishmaniosis (51).

Lip AmB $20 \mathrm{mg} / \mathrm{kg}$ was used in India to treat patients with visceral leishmaniosis. The drug was used with 4 doses of 5-mg/kg for 4-10 days dependent on patient's clinical situation and the severity of the disease; therefore, patients with more severe situations spent a 10-day treatment period $(50,51)$. The AmB deoxycholate IV is the 2nd-line drug because it needs a longer hospitalization (around 30 days) and has greater toxicity than its lipid forms (55). The ABLC, however, provides the possibility that a higher dose of the drug be prescribed to patients by a safer and shorter method (56). Despite being expensive, in a 6-month followup it was observed that it had a lower relapse and was safe and effective (50).

There is also another therapeutic method for this drug. In this method, Lip AmB was used with a single dose of 10 $\mathrm{mg} / \mathrm{kg}$ that was safe and had over 95\% efficacy (57). As mentioned above, Bangladesh is among the countries with a high prevalence of visceral leishmaniosis. Here, a single dose of Lip AmB is used as the safest and the most effective therapy for visceral leishmaniosis. A research carried out in this country revealed that Lip AmB received the highest degree of satisfaction among patients and hospital staff. Moreover, a single dose of this drug has the fewest side effects and reduces the treatment costs. Before the prescription of Lip AmB in Bangladesh, the oral drug of miltefosine was used as the 1st-line treatment of visceral leishmaniosis replaced by Lip AmB due to the advantages presented in Table 5 that led to its superiority to miltefosine and turned it to the 1st-line treatment of visceral leishmaniosis (58).

The single-dose Lip AmB (Slip AmB) is better tolerated and only has some minor side effects such as a mild and short fever upon infusion. Patients receiving this drug indicated a quick recovery and besides satisfaction to use it, they preferred a single-dose infusion to a 28-day use of the pills. Other positive points of using Slip AmB include its $100 \%$ adherence rates and the fact that this drug can be safely used in pregnancy (60).

Some problematic issues in the use of Lip AmB include the necessity for trained forces, infusion instruments and equipment, and the measurement of hemoglobin and other clinical parameters. Moreover, this drug needs some equipment for its special storage conditions to ensure that the drug temperature does not exceed $25^{\circ} \mathrm{C}$ (58).

\section{Persistent Fever and Neutropenia}

Invasive fungal infections are among the important factors creating illness and death in patients with neutropenia under chemotherapy and patients undergoing the transplant of hematopoietic stem cell (61-63).

In such people, the degree of infections resulted from invasive and opportunistic fungal infections is $10 \%$ to 25 $\%$, the degree of mortality resulted from the invasive candidiasis is $35 \%$ to $50 \%$, and the degree of mortality resulted from invasive aspergillosis and other invasive fungal filaments is $65 \%$ to $90 \%(63,64)$. A persistent fever in patients with neutropenia receiving a wide range of antibiotics can be the only clinical symptom of invasive fungal infections (65).

Lip AmB and caspofungin are both important factors to treat invasive fungal infections in the mentioned patients (66).

AmB and its lipid formulations are used as antifungal empirical treatments against many opportunistic fungal infections in patients with persistent fever and neutropenia $(65,67,68)$.

The drug dose chosen for the antifungal experimental treatment of patients with persistent fever and neutropenia was $3 \mathrm{mg} / \mathrm{kg}$ of Lip AmB (69).

Caspofungin is also effective against candidiasis and aspergillosis (65, 70-72) and despite some clinical restrictions, both drugs are used in combination to treat patients with fulminant and recurrent infections, infections in organs that are difficult to treat and infections with agents decreasing the reaction to antifungal factors $(70,73,74)$. Except for a greater hypokalemia observed in the combination therapy of caspofungin and Lip AmB, similar to monotherapy, combination therapy is safe and no interaction is observed between these 2 drugs (66).

7. The Efficacy and Role of Lip AmB in Patients in Need of Renal Replacement Therapy in ICU

In recent years, there was an increased use of RRT in the hospitalized and critically ill patients in ICU. Although in most of the cases RRT is used in patients with acute re- 


\begin{tabular}{|c|c|c|c|}
\hline Indicator & SLip Am N = 299 & Miltefosine $\mathbf{N}=\mathbf{2 2}$ & PValue \\
\hline Resolution of fever in days & $2.48 \pm 0.86$ & $17.58 \pm 11.34$ & $<0.001$ \\
\hline Nausea/vomiting after treatment & $1.3(4)$ & $86.4(19)$ & $<0.001$ \\
\hline Diarrhea & $0.00(0)$ & $63.6(14)$ & $<0.001$ \\
\hline Mean of time to recovery in days & $2.39 \pm 0.731$ & $17.36 \pm 12.385$ & $<0.001$ \\
\hline Mean of time in days to start working after treatment & $2.72 \pm 1.819$ & $52.82 \pm 33.987$ & $<0.001$ \\
\hline Income-loss due to recovery time & 2.72 days $\times 0.30 \$^{\mathrm{b}} / \mathrm{day}=0.816 \$$ & 52.82 days $\times 0.30 \$ /$ day $=15.846 \$$ & $<0.001$ \\
\hline Income-loss (working days lost when receiving treatment) & 2.39 days $\times 0.3 \$ / \mathrm{d}=0.72 \$$ & 17.36 days $\times 0.3 \$ / \mathrm{d}=5.2 \$$ & $<0.001$ \\
\hline
\end{tabular}

nal failure (uremia and metabolic acidosis) to modify the functioning of the kidneys, it is prevalently used to treat other situations such as anasarca (generalized edema), electrolyte disorders, acute intoxication, acute pulmonary edema, and even severe sepsis (75).

The use of RRT can influence the concentration of azoles $(76,77)$. The administration of echinocandins (78, 79 ) and polyenes $(80,81)$, however, has the least degree of change. Therefore, it is not required to monitor plasma concentration and the dose changes in such cases $(16,75)$; and the clinical efficacy of Lip AmB in patients in need of RRT is similar to that of patients with no need to RRT (75).

Table 6 provides a general presentation of the effects of the polyenes class on the kidneys.

8. The Effects of AmpB Formulations in Patients Receiving Liver Transplants and Patients with Liver Problems

Patients receiving liver transplants, especially those who need more than 5 days of hospitalization in ICU, are patients with high risks of afflicting with invasive liver infections (82). Invasive fungal infections upon liver transplant bring about a high degree of mortality and the conducted research showed that there was $18 \%$ to $42 \%$ probability of the occurrence of invasive fungal infections and resulting 50\% to $78 \%$ of mortality in these patients (83-88). Here, Candida spp. is responsible for the majority of infections. However, many of the patients with candidiasis survive while infections created by Aspergillus spp. are almost fatal $(84,85,88)$. The prophylaxis with fluconazole in patients with high risks of invasive fungal infections reduces the occurrence of invasive candidiasis (89). However, there is the possibility of fungus resistance to fluconazole and failure in the prevention from invasive aspergillosis (90). Although fluconazole decreases fungus colonization and the mortality resulted from invasive fungal infections, in general, it improves the patients' survival (91).
AmpB formulations are considered as a choice agent for the prophylaxis of fungal infections resulted from aspergillosis. However, the toxicity resulted from conventional AmpB has limited its use as an antifungal prophylaxis in the liver transplant receivers and has resulted in the prohibition of its use in the liver transplant receivers (92). Generation of lipid-based formulations of amphotericin that are less toxic than the conventional type has led to a higher tendency to use such lipid-based formulations as a prophylaxis (93-96).

Among these lipid forms, ABLC is a lipid form with a high proportion of amphotericin-lipid (1:1) that creates a low plasma concentration, but has greater tissue levels than other lipid formulations of $\mathrm{AmpB}$ (97).

The ABLC is as effective as the conventional type, but it has less toxicity in people with invasive candidiasis and immune deficiency (98).

To have the antifungal prophylaxis in liver transplant receivers, the use of ABLC (Abelect) with a dose of 1 $\mathrm{mg} / \mathrm{kg} /$ day begins 5 days after the transplantation surgery and continues by the time of the patient's hospitalization in the ICU. The prophylaxis with ABLC in patients in need of long hospitalization in ICU after the transplant is tolerated well and prevents the fungal infections (82).

In patients with a liver disease background, the use of amphotericin and its lipid formulations increases the liver enzyme. Table 7 presents the doses related to the mentioned formulations for such patients.

\section{Conclusions}

Studies conducted to-date indicate the effective role of amphotericin B and its lipid formulations to treat invasive fungal diseases in the critically ill patients. 


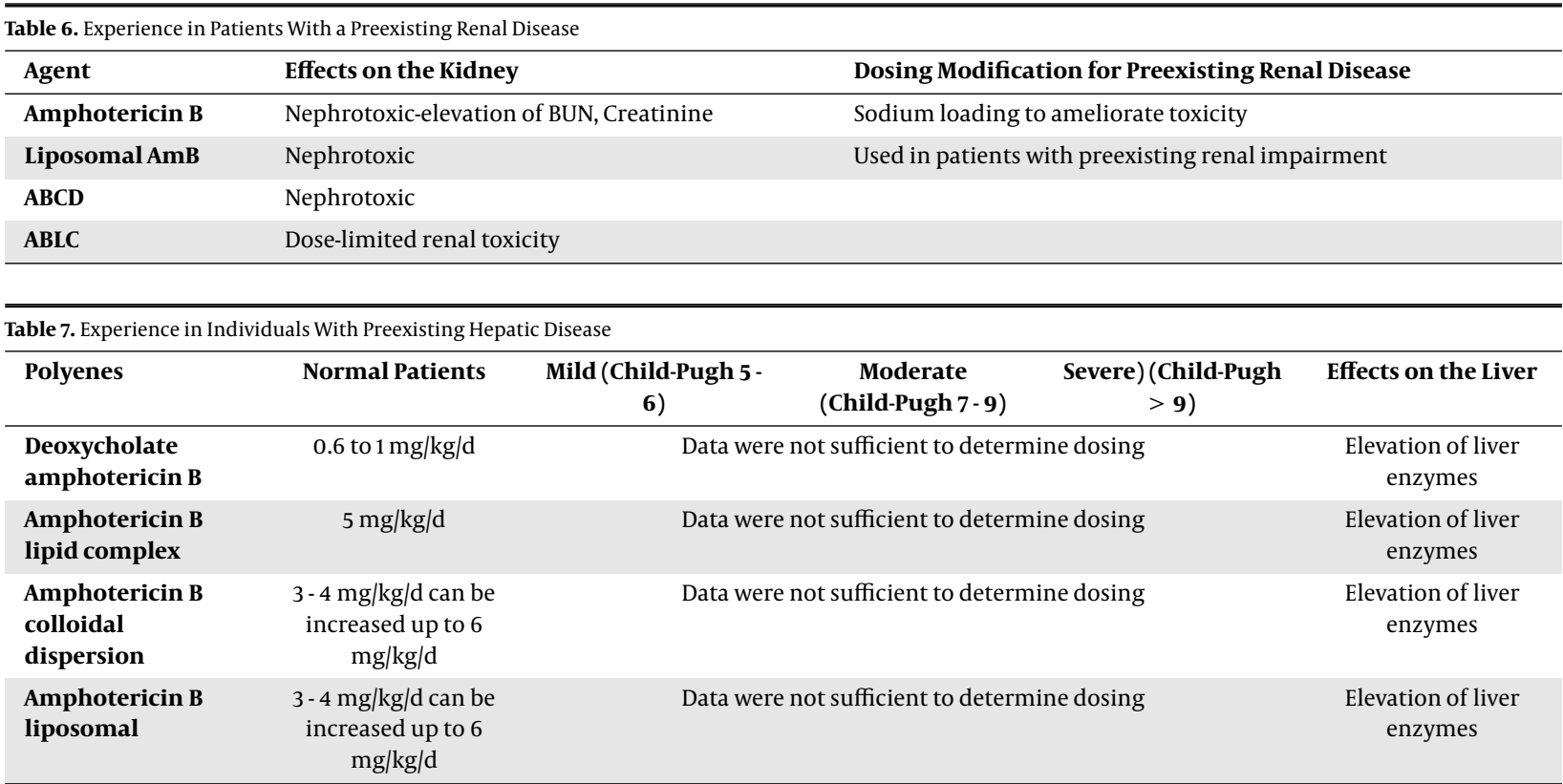

\section{References}

1. Fleming RV, Walsh TJ, Anaissie EJ. Emerging and less common fungal pathogens. Infectious disease clinics of North America. 2002;16(4):91533.

2. Rex JH, Walsh TJ, Anaissie EJ. Fungal infections in iatrogenically compromised hosts. Adv Intern Med. 1998;43:321-71. [PubMed: 9506187].

3. Wisplinghoff H, Bischoff T, Tallent SM, Seifert H, Wenzel RP, Edmond MB. Nosocomial bloodstream infections in US hospitals: analysis of 24,179 cases from a prospective nationwide surveillance study. Clin Infect Dis. 2004;39(3):309-17. doi: 10.1086/421946. [PubMed:15306996].

4. Marsh PK, Tally FP, Kellum J, Callow A, Gorbach SL. Candida infections in surgical patients. Ann Surg. 1983;198(1):42-7. [PubMed: 6407409].

5. D'Amelio LF, Wagner B, Azimuddin S, Sutyak JP, Hammond JS. Antibiotic patterns associated with fungal colonization in critically ill surgical patients. The American surgeon.1995;61(12):1049-53.

6. Rieger CT, Cornely OA, Hoppe-Tichy T, Kiehl M, Knoth H, Thalheimer $\mathrm{M}$, et al. Treatment cost of invasive fungal disease (Ifd) in patients with acute myelogenous leukaemia (Aml) or myelodysplastic syndrome (Mds) in German hospitals. Mycoses. 2012;55(6):514-20. doi: 10.1111/j.1439-0507.2012.02193.x. [PubMed: 22471310].

7. Van Thiel DH, George M, Moore CM. Fungal infections: their diagnosis and treatment in transplant recipients. International journal of hepatology. 2012;2012.

8. Neumann A, Baginski M, Winczewski S, Czub J. The effect of sterols on amphotericin B self-aggregation in a lipid bilayer as revealed by free energy simulations. Biophys J. 2013;104(7):1485-94. doi: 10.1016/j.bpj.2013.02.029. [PubMed: 23561525].

9. Ghannoum MA, Rice LB. Antifungal agents: mode of action, mechanisms of resistance, and correlation of these mechanisms with bacterial resistance. Clin Microbiol Rev. 1999;12(4):501-17. [PubMed: 10515900].

10. Pfaller MA, Messer SA, Boyken L, Tendolkar S, Hollis RJ, Diekema DJ. Geographic variation in the susceptibilities of invasive isolates of Candida glabrata to seven systemically active antifungal agents: a global assessment from the ARTEMIS Antifungal Surveillance Program conducted in 2001 and 2002. J Clin Microbiol. 2004;42(7):3142-6. doi:10.1128/JCM.42.7.3142-3146.2004. [PubMed: 15243073].
11. Sabatelli F, Patel R, Mann PA, Mendrick CA, Norris CC, Hare R, et al. In vitro activities of posaconazole, fluconazole, itraconazole, voriconazole, and amphotericin B against a large collection of clinically important molds and yeasts. Antimicrob Agents Chemother. 2006;50(6):2009-15. doi: 10.1128/AAC.00163-06. [PubMed:16723559].

12. Deray G. Amphotericin B nephrotoxicity. J Antimicrob Chemother. 2002;49 Suppl 1:37-41. [PubMed: 11801579].

13. Paramythiotou E, Frantzeskaki F, Flevari A, Armaganidis A, Dimopoulos G. Invasive fungal infections in the ICU: how to approach, how to treat. Molecules. 2014;19(1):1085-119. doi: 10.3390/molecules19011085. [PubMed: 24445340].

14. Blot S, Vandewoude K. Management of invasive candidiasis in critically ill patients. Drugs. 2004;64(19):2159-75. [PubMed: 15456333].

15. Ostrosky-Zeichner L, Marr KA, Rex JH, Cohen SH. Amphotericin B: time for a new "gold standard". Clin Infect Dis. 2003;37(3):415-25. doi: 10.1086/376634. [PubMed: 12884167$]$.

16. Bellmann R, Egger P, Gritsch W, Bellmann-Weiler R, Joannidis M, Kaneider N, et al. Amphotericin B lipid formulations in critically ill patients on continuous veno-venous haemofiltration. $J$ Antimicrob Chemother. 2003;51(3):671-81. [PubMed:12615870].

17. Mistro S, Maciel Ide M, de Menezes RG, Maia ZP, Schooley RT, Badaro R. Does lipid emulsion reduce amphotericin B nephrotoxicity? A systematic review and meta-analysis. Clin Infect Dis. 2012;54(12):1774-7. doi: 10.1093/cid/cis290. [PubMed: 22491505].

18. Mehta R, Lopez-Berestein G, Hopfer R, Mills K, Juliano RL. Liposomal amphotericin $B$ is toxic to fungal cells but not to mammalian cells. Biochimica et Biophysica Acta (BBA) - Biomembranes. 1984;770(2):230-4. doi: 10.1016/0005-2736(84)90135-4.

19. Chopra R, Blair S, Strang J, Cervi P, Patterson KG, Goldstone AH. Liposomal amphotericin B (AmBisome) in the treatment of fungal infections in neutropenic patients. J Antimicrob Chemother. 1991;28 Suppl B:93-104. [PubMed: 1778896].

20. Heinemann V, Jehn U, Scholz P, Gleixner B, Möhrle W, Wachholz K, et

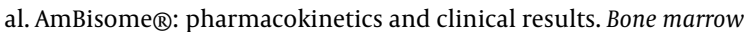
transplantation. Supplement. 1993;12(4):S147-8.

21. Meunier F, Prentice HG, Ringden O. Liposomal amphotericin B (AmBisome): safety data from a phase II/III clinical trial. J Antimicrob Chemother. 1991;28 Suppl B:83-91. [PubMed: 1778895]. 
22. Tollemar J, Ringden O, Tyden G. Liposomal amphotericin-B (AmBisome) treatment in solid organ and bone marrow transplant recipients. Efficacy and safety evaluation. Clinical transplantation. 1990;4(3):167-75.

23. Joly V, Saint-Julien L, Carbon C, Yeni P. Interactions of free and liposomal amphotericin B with renal proximal tubular cells in primary culture. J Pharmacol Exp Ther. 1990;255(1):17-22. [PubMed: 2213553].

24. Lopez-Berestein G, Bodey GP, Fainstein V, Keating M, Frankel LS, Zeluff B, et al. Treatment of systemic fungal infections with liposomal amphotericin B. Arch Intern Med.1989;149(11):2533-6. [PubMed: 2818111].

25. Lopez-Berestein G. Liposomes as carriers of antimicrobial agents. Antimicrob Agents Chemother. 1987;31(5):675-8. [PubMed: 3300535].

26. Shigemi A, Matsumoto K, Ikawa K, Yaji K, Shimodozono Y, Morikawa $\mathrm{N}$, et al. Safety analysis of liposomal amphotericin B in adult patients: anaemia, thrombocytopenia, nephrotoxicity, hepatotoxicity and hypokalaemia. Int J Antimicrob Agents. 2011;38(5):417-20. doi: 10.1016/j.ijantimicag.2011.07.004. [PubMed: 21885259].

27. Sanches BF, Nunes P, Almeida H, Rebelo M. Atrioventricular block related to liposomal amphotericin B. BMJ Case Rep. 2014;2014. doi: 10.1136/bcr-2013-202688. [PubMed: 24907206].

28. Pappas PG, Kauffman CA, Andes D, Benjamin DJ, Calandra TF, Edwards JJ, et al. Clinical practice guidelines for the management of candidiasis: 2009 update by the Infectious Diseases Society of America. Clin Infect Dis. 2009;48(5):503-35. doi: 10.1086/596757. [PubMed: 19191635]

29. Mills EJ, Perri D, Cooper C, Nachega JB, Wu P, Tleyjeh I, et al. Antifungal treatment for invasive Candida infections: a mixed treatment comparison meta-analysis. Ann Clin Microbiol Antimicrob. 2009;8:23. doi: 10.1186/1476-0711-8-23. [PubMed: 19558681].

30. Dreyfuss D, Ricard JD, Gaudry S. Amphotericin B deoxycholate for candidiasis in intensive care unit patients revisited: medical, ethical, and financial implications. Am J Respir Crit Care Med. 2013;187(6):661-3. doi: 10.1164/ajrccm.187.6.661. [PubMed: 23504365].

31. Peleg AY, Woods ML. Continuous and $4 \mathrm{~h}$ infusion of amphotericin B: a comparative study involving high-risk haematology patients. J Antimicrob Chemother. 2004;54(4):803-8. doi: 10.1093/jac/dkh403. [PubMed: 15308606].

32. Cornely OA, Bassetti M, Calandra T, Garbino J, Kullberg BJ, Lortholary O, et al. ESCMID* guideline for the diagnosis and management of Candida diseases 2012: non-neutropenic adult patients. Clin Microbiol Infect. 2012;18 Suppl 7:19-37. doi: 10.1111/1469-0691.12039. [PubMed: 23137135].

33. Kullberg BJ, Verweij PE, Akova M, Arendrup MC, Bille J, Calandra T, et al. European expert opinion on the management of invasive candidiasis in adults. Clin Microbiol Infect. 2011;17 Suppl 5:1-12. doi: 10.1111/j.14690691.2011.03615.x. [PubMed: 21884296].

34. Bow EJ, Evans G, Fuller J, Laverdiere M, Rotstein C, Rennie R, et al. Canadian clinical practice guidelines for invasive candidiasis in adults. Can J Infect Dis Med Microbiol. 2010;21(4):e122-50. [PubMed: 22132006].

35. Ruhnke M, Rickerts V, Cornely OA, Buchheidt D, Glockner A, Heinz W, et al. Diagnosis and therapy of Candida infections: joint recommendations of the German Speaking Mycological Society and the PaulEhrlich-Society for Chemotherapy. Mycoses. 2011;54(4):279-310. doi: 10.1111/j.1439-0507.2011.02040.x. [PubMed: 21672038].

36. Limper AH, Knox KS, Sarosi GA, Ampel NM, Bennett JE, Catanzaro A, et al. An official American Thoracic Society statement: Treatment of fungal infections in adult pulmonary and critical care patients. Am J Respir Crit Care Med. 2011;183(1):96-128. doi: 10.1164/rccm.2008-740ST. [PubMed: 21193785].

37. Marr KA, Carter RA, Boeckh M, Martin P, Corey L. Invasive aspergillosis in allogeneic stem cell transplant recipients: changes in epidemiology and risk factors. Blood. 2002;100(13):4358-66. doi: 10.1182/blood2002-05-1496. [PubMed: 12393425].

38. Lin SJ, Schranz J, Teutsch SM. Aspergillosis case-fatality rate: systematic review of the literature. Clin Infect Dis. 2001;32(3):358-66. doi: 10.1086/318483. [PubMed: 11170942].
39. Ostermann H, Solano C, Jarque I, Garcia-Vidal C, Gao X, Barrueta JA, et al. Cost analysis of voriconazole versus liposomal amphotericin B for primary therapy of invasive aspergillosis among patients with haematological disorders in Germany and Spain. BMC Pharmacology and Toxicology. 2014;15(1):52.

40. Bern C, Chowdhury R. The epidemiology of visceral leishmaniasis in Bangladesh: prospects for improved control. Indian J Med Res. 2006;123(3):275-88. [PubMed:16778310].

41. Millon L, Larosa F, Lepiller Q, Legrand F, Rocchi S, Daguindau E, et al. Quantitative polymerase chain reaction detection of circulating DNA in serum for early diagnosis of mucormycosis in immunocompromised patients. Clin Infect Dis. 2013;56(10):e95-101. doi: 10.1093/cid/cit094. [PubMed: 23420816].

42. Walsh TJ, Anaissie EJ, Denning DW, Herbrecht R, Kontoyiannis DP, Marr KA, et al. Treatment of aspergillosis: clinical practice guidelines of the Infectious Diseases Society of America. Clin Infect Dis. 2008;46(3):327-60. doi: 10.1086/525258. [PubMed: 18177225].

43. Cornely OA, Maertens J, Bresnik M, Ebrahimi R, Dellow E, Herbrecht $\mathrm{R}$, et al. Efficacy outcomes in a randomised trial of liposomal amphotericin B based on revised EORTC/MSG 2008 definitions of invasive mould disease. Mycoses. 2011;54(5):e449-55. doi: 10.1111/j.14390507.2010.01947.x. [PubMed: 21039936].

44. Alcazar-Fuoli L, Mellado E, Alastruey-Izquierdo A, Cuenca-Estrella M, Rodriguez-Tudela JL. Aspergillus section Fumigati: antifungal susceptibility patterns and sequence-based identification. Antimicrob Agents Chemother. 2008;52(4):1244-51. doi: 10.1128/AAC.00942-07. [PubMed: 18212093].

45. Park BJ, Wannemuehler KA, Marston BJ, Govender N, Pappas PG, Chiller TM. Estimation of the current global burden of cryptococcal meningitis among persons living with HIV/AIDS. AIDS. 2009;23(4):525-30. doi: 10.1097/QAD.0b013e328322ffac. [PubMed: 19182676].

46. Perfect JR, Dismukes WE, Dromer F, Goldman DL, Graybill JR, Hamill RJ, et al. Clinical practice guidelines for the management of cryptococcal disease: 2010 update by the infectious diseases society of america. Clin Infect Dis. 2010;50(3):291-322. doi: 10.1086/649858. [PubMed: 20047480].

47. O'connor L, Livermore J, Sharp AD, Goodwin J, Gregson L, Howard SJ, et al. Pharmacodynamics of liposomal amphotericin B and flucytosine for cryptococcal meningoencephalitis: safe and effective regimens for immunocompromised patients. The Journal of infectious diseases. 2013;208(2):351-61.

48. Chappuis F, Sundar S, Hailu A, Ghalib H, Rijal S, Peeling RW, et al. Visceral leishmaniasis: what are the needs for diagnosis, treatment and control? Nat Rev Microbiol. 2007;5(11):873-82. doi: 10.1038/nrmicro1748. [PubMed: 17938629].

49. Alvar J, Velez ID, Bern C, Herrero M, Desjeux P, Cano J, et al. Leishmaniasis worldwide and global estimates of its incidence. PLoS One. 2012;7(5). e35671. doi: 10.1371/journal.pone.0035671. [PubMed: 22693548].

50. Burza S, Sinha PK, Mahajan R, Lima MA, Mitra G, Verma N, et al. Fiveyear field results and long-term effectiveness of $20 \mathrm{mg} / \mathrm{kg}$ liposomal amphotericin B (Ambisome) for visceral leishmaniasis in Bihar, India. PLoS neglected tropical diseases. 2014;8(1). e2603.

51. Salih NA, van Griensven J, Chappuis F, Antierens A, Mumina A, Hammam $\mathrm{O}$, et al. Liposomal amphotericin B for complicated visceral leishmaniasis (kala-azar) in eastern Sudan: how effective is treatment for this neglected disease? Trop Med Int Health. 2014;19(2):146-52. doi: 10.1111/tmi.12238. [PubMed: 24433217].

52. Elnaiem DE. Ecology and control of the sand fly vectors of Leishmania donovani in East Africa, with special emphasis on Phlebotomus orientalis. J Vector Ecol. 2011;36 Suppl 1:S23-31. doi: 10.1111/j.19487134.2011.00109.x. [PubMed: 21366778].

53. Collin S, Davidson R, Ritmeijer K, Keus K, Melaku Y, Kipngetich S, et 
al. Conflict and kala-azar: determinants of adverse outcomes of kalaazar among patients in southern Sudan. Clin Infect Dis. 2004;38(5):6129. doi: 10.1086/381203. [PubMed: 14986243].

54. Bern C, Adler-Moore J, Berenguer J, Boelaert M, den Boer M, Davidson RN, et al. Liposomal amphotericin B for the treatment of visceral leishmaniasis. Clin Infect Dis. 2006;43(7):917-24. doi: 10.1086/507530. [PubMed: 16941377].

55. World Health Organisation. Control of the leishmaniasis: Report of a meeting of the WHO Expert Committee on the Control of Leishmaniases. Technical Report Series No. 949. Geneva; 2010. Available from: http:// whqlibdoc.who.int/trs/WHO_TRS 949 eng.pdf.

56. Balasegaram M, Ritmeijer K, Lima MA, Burza S, Ortiz Genovese G, Milani B, et al. Liposomal amphotericin B as a treatment for human leishmaniasis. Expert Opin Emerg Drugs. 2012;17(4):493-510. doi: 10.1517/14728214.2012.748036. [PubMed: 23167833].

57. Sundar S, Chakravarty J, Agarwal D, Rai M, Murray HW. Single-dose liposomal amphotericin B for visceral leishmaniasis in India. N Engl J Med. 2010;362(6):504-12. doi: 10.1056/NEJMoa0903627. [PubMed: 20147716].

58. Maintz EM, Hassan M, Huda MM, Ghosh D, Hossain MS, Alim A, et al. Introducing single dose liposomal amphotericin $\mathrm{B}$ for the treatment of visceral leishmaniasis in rural bangladesh: feasibility and acceptance to patients and health staff. J Trop Med. 2014;2014:676817. doi: 10.1155/2014/676817. [PubMed: 24578710].

59. Anoopa Sharma D, Bern C, Varghese B, Chowdhury R, Haque R, Ali M, et al. The economic impact of visceral leishmaniasis on households in Bangladesh. Trop Med Int Health. 2006;11(5):757-64. doi: 10.1111/j.13653156.2006.01604.x. [PubMed: 16640630].

60. Dorlo TP, Balasegaram M, Beijnen JH, de Vries PJ. Miltefosine: a review of its pharmacology and therapeutic efficacy in the treatment of leishmaniasis. J Antimicrob Chemother. 2012;67(11):2576-97. doi: 10.1093/jac/dks275. [PubMed: 22833634].

61. Andriole VT. Infections with Aspergillus species. Clinical Infectious Diseases.1993;17(Supplement_2):481-6.

62. Pannuti C, Gingrich R, Pfaller MA, Kao C, Wenzel RP. Nosocomial pneumonia in patients having bone marrow transplant. Attributable mortality and risk factors. Cancer. 1992;69(11):2653-62. [PubMed:1315207].

63. Bow EJ. Invasive fungal infection in haematopoietic stem cell transplant recipients: epidemiology from the transplant physician's viewpoint. Mycopathologia. 2009;168(6):283-97. doi: 10.1007/s11046-0099196-6. [PubMed: 19343534].

64. Groll AH, Tragiannidis A. Recent advances in antifungal prevention and treatment. Semin Hematol. 2009;46(3):212-29. doi: 10.1053/j.seminhematol.2009.03.003. [PubMed: 19549575].

65. Walsh TJ, Teppler H, Donowitz GR, Maertens JA, Baden LR, Dmoszynska A, et al. Caspofungin versus liposomal amphotericin B for empirical antifungal therapy in patients with persistent fever and neutropenia. N Engl J Med. 2004;351(14):1391-402. doi: 10.1056/NEJMoa040446. [PubMed: 15459300].

66. Wurthwein G, Young C, Lanvers-Kaminsky C, Hempel G, Trame MN, Schwerdtfeger R, et al. Population pharmacokinetics of liposomal amphotericin $\mathrm{B}$ and caspofungin in allogeneic hematopoietic stem cell recipients. Antimicrob Agents Chemother. 2012;56(1):536-43. doi: 10.1128/AAC.00265-11. [PubMed: 22083471].

67. Mousset S, Buchheidt D, Heinz W, Ruhnke M, Cornely OA, Egerer $\mathrm{G}$, et al. Treatment of invasive fungal infections in cancer patientsupdated recommendations of the Infectious Diseases Working Party (AGIHO) of the German Society of Hematology and Oncology(DGHO). Ann Hematol. 2014;93(1):13-32. doi:10.1007/s00277-013-1867-1. [PubMed: 24026426].

68. Spellberg B, Walsh TJ, Kontoyiannis DP, Edwards JJ, Ibrahim AS. Recent advances in the management of mucormycosis: from bench to bedside. Clin Infect Dis. 2009;48(12):1743-51. doi: 10.1086/599105. [PubMed: 19435437].

69. Walsh TJ, Finberg RW, Arndt C, Hiemenz J, Schwartz C, Bodensteiner
D, et al. Liposomal amphotericin B for empirical therapy in patients with persistent fever and neutropenia. National Institute of Allergy and Infectious Diseases Mycoses Study Group. N Engl J Med. 1999;340(10):764-71. doi: 10.1056/NEJM199903113401004. [PubMed: 10072411].

70. Maertens J, Glasmacher A, Herbrecht R, Thiebaut A, Cordonnier C, Segal $\mathrm{BH}$, et al. Multicenter, noncomparative study of caspofungin in combination with other antifungals as salvage therapy in adults with invasive aspergillosis. Cancer. 2006;107(12):2888-97. doi: 10.1002/cncr.22348. [PubMed: 17103444].

71. Mora-Duarte J, Betts R, Rotstein C, Colombo AL, Thompson-Moya L, Smietana J, et al. Comparison of caspofungin and amphotericin B for invasive candidiasis. N Engl J Med. 2002;347(25):2020-9. doi 10.1056/NEJMoa021585. [PubMed: 12490683].

72. Pappas PG, Rotstein CM, Betts RF, Nucci M, Talwar D, De Waele JJ, et al. Micafungin versus caspofungin for treatment of candidemia and other forms of invasive candidiasis. Clin Infect Dis. 2007;45(7):883-93. doi: 10.1086/520980. [PubMed: 17806055].

73. Ascioglu S, Rex JH, de Pauw B, Bennett JE, Bille J, Crokaert F, et al. Defining opportunistic invasive fungal infections in immunocompromised patients with cancer and hematopoietic stem cell transplants: an international consensus. Clin Infect Dis. 2002;34(1):7-14. doi 10.1086/323335. [PubMed: 11731939].

74. Reed C, Bryant R, Ibrahim AS, Edwards IJ, Filler SG, Goldberg $\mathrm{R}$, et al. Combination polyene-caspofungin treatment of rhinoorbital-cerebral mucormycosis. Clin Infect Dis. 2008;47(3):364-71. doi: 10.1086/589857. [PubMed: 18558882 ].

75. Alvarez-Lerma F, Rodriguez M, Soriano MC, Catalan M, Llorente AM Vidart N, et al. Effectiveness of liposomal amphotericin B in patients admitted to the ICU on renal replacement therapy. Rev Esp Quimioter. 2013;26(4):360-8. [PubMed: 24399350].

76. Patel K, Roberts JA, Lipman J, Tett SE, Deldot ME, Kirkpatrick CM Population pharmacokinetics of fluconazole in critically ill patients receiving continuous venovenous hemodiafiltration: using Monte Carlo simulations to predict doses for specified pharmacodynamic targets. Antimicrob Agents Chemother. 2011;55(12):5868-73. doi: 10.1128/AAC.00424-11. [PubMed: 21930888].

77. Hafner V, Czock D, Burhenne J, Riedel KD, Bommer J, Mikus G, et al. Pharmacokinetics of sulfobutylether-beta-cyclodextrin and voriconazole in patients with end-stage renal failure during treatment with two hemodialysis systems and hemodiafiltration. Antimicrob Agents Chemother. 2010;54(6):2596-602. doi: 10.1128/AAC.0154009. [PubMed: 20368400].

78. Burkhardt O, Kaever V, Burhenne H, Kielstein JT. Extended daily dialysis does not affect the pharmacokinetics of anidulafungin. Int JAntimicrob Agents. 2009;34(3):282-3. doi: 10.1016/j.ijantimicag.2009.03.003. [PubMed: 19369040].

79. Hirata K, Aoyama T, Matsumoto Y, Ogawa F, Yamazaki H, Kikuti A, et al Pharmacokinetics of antifungal agent micafungin in critically ill patients receiving continuous hemodialysis filtration. Yakugaku Zasshi. 2007;127(5):897-901. [PubMed: 17473532].

80. Bellmann R, Egger P, Djanani A, Wiedermann CJ. Pharmacokinetics of amphotericin B lipid complex in critically ill patients on continuous veno-venous haemofiltration. Int J Antimicrob Agents. 2004;23(1):80-3. [PubMed: 14732318].

81. Heinemann V, Bosse D, Jehn U, Kahny B, Wachholz K, Debus A, et al. Pharmacokinetics of liposomal amphotericin B (Ambisome) in critically ill patients. Antimicrob Agents Chemother. 1997;41(6):1275-80. [PubMed: 9174183].

82. Singhal S, Ellis RW, Jones SG, Miller SJ, Fisher NC, Hastings JG, et al. Targeted prophylaxis with amphotericin B lipid complex in liver transplantation. LiverTranspl.2000;6(5):588-95. doi: 10.1053/jlts.2000.7572. [PubMed: 10980058].

83. Schroter GP, Hoelscher M, Putnam CW, Porter KA, Starzl TE. Fun- 
gus infections after liver transplantation. Ann Surg. 1977;186(1):115-22. [PubMed: 327951].

84. Wajszczuk CP, Dummer JS, Ho M, Van Thiel DH, Starzl TE, Iwatsuki S. Fungal infections in liver transplant recipients. Transplantation. 1985;40:347-53.

85. Kusne S, Dummer JS, Singh N, Iwatsuki S, Makowka L, Esquivel C, et al. Infections after liver transplantation. An analysis of 101 consecutive cases. Medicine (Baltimore). 1988;67(2):132-43. [PubMed: 3280944].

86. Colonna J2, Winston DJ, Brill JE, Goldstein LI, Hoff MP, Hiatt JR, et al. Infectious complications in liver transplantation. Arch Surg. 1988;123(3):360-4. [PubMed: 2829792].

87. Tollemar J, Ericzon BG, Holmberg K, Andersson J. The incidence and diagnosis of invasive fungal infections in liver transplant recipients. Transplant Proc. 1990;22(1):242-4. [PubMed: 2309321].

88. Castaldo P, Stratta RJ, Wood RP, Markin RS, Patil KD, Shaefer MS, et al. Clinical spectrum of fungal infections after orthotopic liver transplantation. Arch Surg. 1991;126(2):149-56. [PubMed: 1992992].

89. Kung N, Fisher N, Gunson B, Hastings M, Mutimer D. Fluconazole prophylaxis for high-risk liver transplant recipients. Lancet. 1995;345(8959):1234-5. [PubMed: 7739317].

90. Fisher NC, Cooper MA, Hastings JG, Mutimer DJ. Fungal colonisation and fluconazole therapy in acute liver disease. Liver. 1998;18(5):320-5. [PubMed: 9831360].

91. Winston DJ, Pakrasi A, Busuttil RW. Prophylactic fluconazole in liver transplant recipients. A randomized, double-blind, placebo- controlled trial. Ann Intern Med. 1999;131(10):729-37. [PubMed: 10577295].

92. Warnock DW. Amphotericin B: an introduction. J Antimicrob Chemother. 1991;28 Suppl B:27-38. [PubMed: 1778890].

93. de Marie S, Janknegt R, Bakker-Woudenberg IA. Clinical use of liposomal and lipid-complexed amphotericin B. J Antimicrob Chemother. 1994;33(5):907-16. [PubMed: 8089064].

94. Tollemar J, Ringden O. Lipid formulations of amphotericin B. Less toxicity but at what economic cost? Drug Saf.1995;13(4):207-18. [PubMed: 8573294].

95. Hiemenz JW, Walsh TJ. Lipid formulations of amphotericin B: recent progress and future directions. Clin Infect Dis.1996;22 Suppl 2:S133-44. [PubMed: 8722841].

96. Richardson MD. Lipid complexes of amphotericin B: the competitive picture. J Med Microbiol. 1997;46(3):185-7. doi: 10.1099/00222615-46-3185. [PubMed: 9126817].

97. Mehta J. Do variations in molecular structure affect the clinical efficacy and safety of lipid-based amphotericin B preparations? Leuk Res. 1997;21(3):183-8. [PubMed: 9111161].

98. Anaissie E. J , White M. H , Uzun O , Singer C , Bodey G. P , Azarnia N . Amphotericin B lipid complex vs amphotericin B for treatment of haematogenous and invasive candidiasis: A prospective, randomized, multicentre trial. Proc 35th Intersci Conf Antimicrob Agents Chemother. 1995. 